\title{
Unikanie, uległość, troska... woń ciała w społeczno-kulturowym konstruowaniu Obcego
}

\author{
Maria Katarzyna Przybylska \\ (Di) https://orcid.org/0000-0002-8753-8975
}

\begin{abstract}
Rozpoznanie znaczenie powonienia w poznaniu człowieka $\mathrm{w}$ dyscyplinach humanistycznych należy uznać za niedostateczne, choć w ostatnich latach obserwuje się wzrost zainteresowania tą tematyką, również wśród badaczy kultury. W niniejszym artykule rolę powonienia w społecznym poznaniu człowieka przeanalizowano z perspektywy ewolucyjnej, historycznej i neurobiologicznej. Starano się wykazać, że kształtowanie nastawień wobec innych może niezwykle efektywnie operować wyobrażeniami odnoszącymi się do woni ciała. Poszukiwano biologicznych mechanizmów, które potencjalnie decydują o skuteczności odwołań do powonienia jako kulturowego narzędzia wytyczania społecznych granic i manipulacji postrzeganiem jednostek w kategoriach „swój”, Inny, Obcy. Celem, jaki stawia sobie autorka, jest zwiększenie świadomości w zakresie możliwej efektywności wykluczającego wpływu języka odnoszącego się do woni ciała, oraz wzbudzenie czujności u odbiorców takich komunikatów.
\end{abstract}

Słowa kluczowe: powonienie, woń ciała, wstręt, ewolucja wstrętu, obcy, wykluczenie

Badania neuronaukowe nad mechanizmami poznawczymi człowieka często uzmysławiają nam, jak bardzo przeceniamy poznanie oparte na pojęciach. Tradycja dualizmu kartezjańskiego, poparta późniejszym podziałem niemieckim na nauki o duchu i nauki o przyrodzie, na długi czas właściwie wyrugowała z humani-

MARIA KATARZYNA PRZYBYLSKA, Instytut Filozofii, Wydział Humanistyczny, Uniwersytet Mikołaja Kopernika w Toruniu; adres do korespondencji: ul. Fosa Staromiejska 1a, 87-100 Toruń; e-mail: stellaskygge@gmail.com 
stycznych rozważań akademickich tematykę związaną z doświadczeniem bezpośrednim, cielesnym. Także rola węchu ludzkiego w poznaniu społecznym oraz opisów woni i kreowaniu woni w kulturze wydaje się niedoszacowana, o czym w 2007 roku przypomniały między innymi badania J. Porter i współpracowników ${ }^{1}$.

Jak zauważa autor niezwykle popularnej przed kilku laty powieści Pachnidło Patrick Süskind: „Ludzie [...] mogą zamykać oczy na wielkość, na grozę, na piękno. I mogą zamykać uszy na melodię albo bałamutne słowa. Ale nie mogą uciec przed zapachem. Zapach bowiem jest bratem oddechu. Zapach wnika do ludzkiego wnętrza wraz z oddechem ludzie nie mogą się przed nim obronić, jeżeli chcą żyć”" To właśnie przy wyczuwaniu zapachu dochodzi do pierwszego fizycznego kontaktu z obiektem, od którego rozpoznawane cząstki pochodzą, a wąchanie jest znacznie bliższe smakowaniu, niż się na ogół potocznie przyjmuje. Z drugiej strony, w codziennym doświadczeniu spostrzegamy, że zapach często jest pierwszym sygnałem, który ostrzega przed możliwością skażenia czy innym niebezpieczeństwem, gdyż nim jeszcze człowiek zetknie się z jego źródłem ciałem lub odzieżą, czuje już zapach w powietrzu. Jak starano się niżej wykazać, to powonienie pozwala najszybciej odróżnić to, co czyste od nieczystego, w sensie znacznie szerszym niż sens odnoszący się do klinicznej sterylności, ale też czystości moralnej.

Postawiona w tytule hipoteza o istotnej roli wyobrażeń odnoszących się do woni ciała ludzkiego w wyznaczaniu barier kulturowych może nie od razu wydać się przekonująca: między subiektywnym doświadczaniem zapachu innej osoby jako przykrego a wrogością i przemocą nie ma prostego, bezpośredniego związku. Zależność pomiędzy tymi pozornie luźno powiązanymi zjawiskami może stać się

\footnotetext{
${ }^{1} \mathrm{~W}$ badaniach tych wykazano eksperymentalnie, że przy deprywacji wzrokowej człowiek jest zdolny do kierowania się ścieżką zapachową i dyskryminacji źródeł woni z rozdzielczością przestrzenną do $35 \mathrm{~mm}$. Podobnie jak inne ssaki, człowiek kieruje się wonią poprzez analizę asymetrii natężenia bodźca docierającego do obu nozdrzy i jest zdolny doskonalić tę umiejętność poprzez jej ćwiczenie; Jess Porter i in., „Mechanisms of scent-tracking in humans”, Nature neuroscience 10, nr 1 (2007): 27, DOI: https://dx.doi.org/10.1038/nn1819

${ }^{2}$ Patrick Süskind, Pachnidło: historia pewnego mordercy, tłum. Małgorzata Łukasiewicz (Warszawa: Świat Książki, 2006), 261.
} 
łatwiej zauważalna, gdy uwzględni się rolę, jaką w społeczno-kulturowym konstruowaniu obcości, w oparciu o system pojęć odnoszących się do woni ciała, spełnia silnie kojarzące zjawisko emocji, a w szczególności emocja wstrętu.

Ujmując rzecz niezwykle skrótowo, Innym w ujęciu fenomenologicznym jest to doświadczające, żywe ciało, z którym możemy współodczuwać, z którym łączy nas wspólna sfera przeżywania intersubiektywnych emocji, współteraźniejszość, intercielesność ${ }^{3}$. Inny jest taki jak ja, ale nie ten sam. W odróżnieniu od Innego, Obcy jest tym, którego się do tych stref nie dopuszcza, gdyż, w nawiązaniu do koncepcji J. Kristevej, jest wyrazem wszystkiego tego, czego nie akceptujemy w nas samych ${ }^{4}$. Starając się przybliżyć rolę, jaką woń ciała pełni w ustanawianiu społeczno-kulturowych granic, wychodzę od biologicznej roli powonienia, starając się następnie pokazać, jak poprzez stopniowe, ewolucyjne rozszerzanie kategorii wstrętu z emocji warunkowanej bodźcami o znaczeniu czysto biologicznym, w szczególności olfaktorycznymi, ku reakcji autonomicznej na bodźce coraz bardziej abstrakcyjne, aż po naruszenia norm społecznych. Podaję również przykłady posługiwania się wyobrażeniami odnoszącymi się do zapachu jako narzędziem tworzenia dystansu i społecznego wykluczenia.

\section{Biologiczne i kulturowe znaczenie powonienia}

Zakres, w jakim świat ożywiony przekazuje sobie informacje za pośrednictwem emisji związków chemicznych do środowiska, jest bardzo szeroki. Zachowania tego rodzaju obserwowane są już na poziomie organizmów jednokomórkowych: komunikacja międzykomórkowa bakterii jest szczególnie ważna w produkcji biofilmu komórkowego ${ }^{5}$, oraz emisji toksyn i innych czynników wirulentnych ${ }^{6}$, a także w kooperacji tych organizmów na poziomie współtworzonych przez

${ }^{3}$ Marek Pokrospki, Cielesna geneza czasu i przestrzeni (Warszawa: Wydawnictwo IFiS PAN, 2013), 251 i n.

${ }^{4}$ Julia Kristeva, Potęga obrzydzenia: esej o wstręcie, tłum. Maciej Falski (Kraków: Wydawnictwo Uniwersytetu Jagiellońskiego, 2007).

${ }^{5}$ David G. Davies i in., „The involvement of cell-to-cell signals in the development of a bacterial biofilm", Science 280, nr 5361 (1998): 295-298, DOI: https://dx.doi.org/10.1126/science.280.5361.295

${ }^{6}$ Luciano Passador i in., „Expression of Pseudomonas aeruginosa virulence genes requires cellto-cell communication", Science 260, nr 5111 (1993): 1127-1130, DOI: https://dx.doi.org/10.1126/science.8493556 
nie kolonii ${ }^{7}$. Komunikacja fitoferomonalna odgrywa ważną rolę w funkcjonowaniu skupisk roślin ${ }^{8}$, w których sygnały chemiczne biorą udział także w identyfikacji bliskości pokrewieństwa z innymi osobnikami ${ }^{9}$. Istnieją organizmy - na przykład owady społeczne tworzące rozbudowane kolonie - które są w stanie, korzystając z wielu feromonalnych gruczołów sekrecyjnych, wydzielać mieszanki związków łączonych w różnych proporcjach, tworząc w ten sposób zrozumiałe dla innych osobniczek „wypowiedzi”. Oprócz komunikatów doraźnych, okazjonalnych, każda kolonia odznacza się własnym niepowtarzalnym zapachem. To woń osobniczek identyfikuje ich przynależność do kolonii i miejsce zajmowane w jej hierarchii ${ }^{10}$. U organizmów wyżej zorganizowanych, woń ciała również stanowi podstawowe narzędzie bezpośredniej identyfikacji członków stada, mieszkańców gniazda, modyfikuje również wzorce prawdopodobieństwa przystępowania do interakcji społecznych ${ }^{11}$. O wysokiej biologicznej istotności szybkiego rozpoznawania i właściwego reagowania na bodźce zapachowe wnioskować można nie tylko z ilości genów, jaka koduje białka odpowiedzialne za identyfikację cząsteczek zapachowych u ssaków i samego człowieka ${ }^{12}$, ale również z faktu, że przeżyciowe warunkowanie na bodziec zapachowy w określonych warunkach może podlegać

\footnotetext{
${ }^{7}$ Gary M. Dunny, Timothy J. Brickman i Martin S. Dworkin, „Multicellular behavior in bacteria: communication, cooperation, competition and cheating", BioEseys 30, $\mathrm{nr} 4$ (2008): 296-298, DOI: https://dx.doi.org/10.1002/bies.20740

${ }^{8}$ Sylvia Hughes, „Antelope Activate the Acacia’s Alarm System”, New Scientist 127, nr 29 (1990): 19; Richard Karban, Louie H. Yang i Kyle F. Edwards, „Volatile communication between plants that affects herbivory: a meta-analysis", Ecology Letters 17, nr 1 (2014): 44-52.

${ }^{9}$ Richard Karban, Kaori Shiojiri, „Self-recognition affects plant communication and defence”, Ecology Letters 12, nr 6 (2009): 502-506, DOI: https://dx.doi.org/10.1111/j.1461-0248.2009.01313.x; Richard Karban i in., „Kin recognition affects plant communication and defence”, Proceedings of the Royal Society B 280, nr 1756 (2013), DOI: https://dx.doi.org/10.1098/rspb.2012.3062

${ }^{10}$ Johan Billen, „Exocrine glands and their key function in the communication system of social insects”, Formosan Entomology 2011, nr 31, 75-84; Freddie-Jeanne Richard, James H. Hunt, „Intracolony chemical communication in social insects", Insectes Sociaux 60, nr 3 (2013): 275-291, DOI: https://dx.doi.org/10.1007/s00040-013-0306-6

${ }^{11}$ Tania Singer i in., „Empathic neural responses are modulated by the perceived fairness of others", Nature 439, nr 7075 (2008): 466, DOI: https://dx.doi.org/10.1038/nature04271

${ }^{12}$ Linda Buck i Richard Axel, „A novel multigene family may encode odorant receptors: a molecular basis for odor recognition", Cell 65, nr 1 (1991): 175-187, DOI: https://dx.doi.org/10.1016/00928674(91)90418-x
} 
dziedziczeniu lamarckowskiemu ${ }^{13}$. Nabłonek węchowy jest jednym $\mathrm{z}$ tych rejonów, w których neurogeneza trwa przez całe ludzkie życie, a komórki dwubiegunowe mogą proliferować i regenerować się ${ }^{14}$.

Człowiek i zwierzęta wyższe posiadają dwa odrębne systemy analizy informacji chemicznej: gustatoryczny i olfaktoryczny. To, co rozumiemy przez zapach, jest silnie uwarunkowane przez środowisko, w jakim żyjemy. Powonienie inaczej definiuje się u stworzeń powietrznych i lądowych, odmiennie zaś u organizmów wodnych. Potocznie uważa się, że zmysł węchu służy do dyskryminacji kompozycji cząsteczek rozproszonych w powietrzu, podczas gdy zmysł smaku pozwala na rozpoznawanie substancji przyjmowanych do jamy gębowej, w czym uczestniczą często wrażenia węchowe. W przypadku zwierząt wodnych granica pomiędzy obiegowo rozumianym powonieniem i smakiem zaciera się, bowiem wszystkie zewnętrzne bodźce chemiczne to cząsteczki rozpuszczone w wodzie, dlatego zmysł smaku od zmysłu węchu u tych organizmów rozróżnia się na tej podstawie, że pierwszy pozwala rozpoznać bodziec w bezpośrednim kontakcie, natomiast drugi służy do detekcji i dyskryminacji bodźca odległego ${ }^{15}$.

Mając na uwadze powyższe, za każdym razem, gdy poniżej brać się będzie pod uwagę rolę bodźców chemicznych w przeżywaniu emocji wstrętu, a gdy mowa jest o smaku, będzie się tutaj rozważać również poprzedzającą przyjmowanie pożywienia, współtowarzyszącą mu woń.

W porównaniu do warunków panujących w świecie ożywionym, ludzkie środki manipulacji wonią własnego ciała wydają się wysoce ograniczone. Zapach wydzielany przez ludzką skórę zależy jednak również od wielu czynników, najczęściej nieuświadamianych, a nierzadko regulowanych przez normy kulturowe,

${ }^{13}$ Brian G. Dias i Kerry J. Ressler, „Parental olfactory experience influences behavior and neural structure in subsequent generations", Nature neuroscience 17, $\mathrm{nr} 1$ (2014): 89, DOI: https://dx.doi.org/10.1038/nn.3594; Moshe Szyf, „Lamarck revisited: epigenetic inheritance of ancestral odor fear conditioning", Nature Neuroscience 17, $\mathrm{nr} 1$ (2014): 2-4, DOI: https://dx.doi.org/ 10.1038/nn.3603

${ }^{14}$ David F. Felten i Anil N. Shetty, Atlas neuroanatomii i neurofizjologii Nettera, red. wydania polskiego Andrzej Szczudlik (Wrocław: Elsevier Urban \& Partner, 2012), 320.

${ }^{15}$ Gianluca Polese, Carla Bertapelle i Anna Di Cosmo, „Role of olfaction in Octopus vulgaris reproduction", General and Coparative Endocrinology 210, $\mathrm{nr} 1$ (2015): 55-62, DOI: https://dx.doi.org/10.1016/j.ygcen.2014.10.006 
w sposób oczywisty bowiem ludzkie ciało nie tylko emituje pewne cząsteczki zapachowe, ale również przejmuje zapachy związane z otoczeniem i rodzajami aktywności jednostki.

Molekuły naturalnego zapachu ciała ludzkiego, identycznie jak u większości ssaków, pochodzą głównie z gruczołów skóry, wydychanego powietrza, krwi i uryny. Zapach wydzielany przez ciało ludzkie nie jest stały, a zależny od metabolizmu, a więc również od chorób o rozmaitej genezie, a jego komponenty mogą stanowić naturalne biomarkery do określania tych chorób ${ }^{16}$. Inne założenie przyjmuje się w doktrynie prawa karnego, w odniesieniu do śladów osmologicznych, gdyż przedmiotem zainteresowania ekspertyzy osmologicznej jest tzw. zapach indywidualny. W doktrynie, mimo wielu wątpliwości, przyjmuje się, że jest on zależny przede wszystkim od genomu ludzkiego, oraz, że daje się wyodrębnić jako ogólna woń mieszaniny zapachów miejscowych ciała, cechująca się niezmiennością, nieusuwalnością i niepowtarzalnością, pomimo różnic w czasie zależnych od wieku, diety, stylu życia, stanu zdrowia, farmakoterapii itd. ${ }^{17}$

Filogenetyczna „dawność” zmysłu powonienia zadecydowała o szybkim przewodzeniu impulsów z nabłonka węchowego do kory analizującej tę informację. Żaden inny zmysł nie może równać się z węchem, jeżeli chodzi o szybkość wywoływanej odpowiedzi emocjonalnej. Nabłonek węchowy człowieka ma bezpośrednie połączenia nerwowe z korą limbiczną. Komórki dwubiegunowe są neuronami przewodzącymi, ale zarazem chemoreceptorami bezpośrednio stycznymi ze środowiskiem zewnętrznym. W opuszce węchowej znajdują się komórki mitralne i pędzelkowate, które mają bezpośrednie projekcje do struktur limbicznych przodomózgowia (w tym ciał migdałowatych), z pominięciem wzgórza, w którym analizowane są informacje pochodzące z wszystkich innych zmysłów. Neurony opuszki węchowej wpływają za to bezpośrednio na podwzgórze, a przez nie na gospodarkę endokrynną i reakcje autonomiczne organizmu, co przekłada się na

${ }^{16}$ Mika Shirasu i Kazushige Touhara, „The scent of disease: volatile organic compounds of the human body related to disease and disorder", The Journal of Biochemistry 150, nr 3 (2011): 257-266, DOI: https://dx.doi.org/10.1093/jb/mvr090

${ }^{17}$ Por. Dagmara Miler, „Pozyskiwanie dowodu przy wykorzystaniu ekspertyzy osmologicznej”, w: Katalog dowodów w postępowaniu karnym, red. Paweł Czarnecki, Małgorzata Czerwińska (Warszawa: Wydawnictwo C. H. Beck, 2014), 257-268. 
aktywność całego organizmu. Za interpretację bodźców zapachowych odpowiadają przede wszystkim kora około-oczodołowa, jądro wzgórza grzbietowe przyśrodkowe, przednia część płata skroniowego ${ }^{18}$.

Podobnie jak w przypadku struktur odpowiedzialnych za przewodzenie i analizę informacji pochodzącej ze zmysłu powonienia, również struktury łączone $\mathrm{w}$ badaniach neuropsychologicznych $\mathrm{z}$ doznawaniem wstrętu są filogenetycznie dawne. Reakcję tę najczęściej łączy się z aktywacją w przednim rejonie wyspy, która u prymatów jest korą sensoryczną, analizującą bodźce smakowe. U człowieka stwierdza się również aktywacje tego regionu w odpowiedzi na prezentację bodźców niezwiązanych z pożywieniem, takich jak okaleczenia czy ekspozycja na twarze wyrażające wstręt ${ }^{19}$.

\section{Biologiczne i kulturowe znaczenie wstrętu}

W klasycznej pracy Wyraz uczuć u ludzi i zwierząt Darwin poszukiwał biologicznego, ewolucyjnego uzasadnienia określonych reakcji emocjonalnych oraz towarzyszących im form ekspresji cielesnej - tak u ludzi, jak u zwierząt. W rozważaniach tych nie pomijał również wstrętu, tak opisując zachowanie związane z jego doświadczeniem: „[...] wyciągamy wargi i podnosimy je, albo samą tylko wargę górną, chcąc dziurki nosa zamknąć, jak gdyby klapą, przy czym nos naturalnie w górę się unosi. Postępujemy tak, jak gdyby chcąc powiedzieć pogardzonej osobie, że nieprzyjemnie pachnie, jak kiedy przez współzamknięcie powiek lub odwrócenie twarzy chcemy jej wyrazić, że nie warta jest, by na nią patrzeć" ${ }^{20}$. Darwin zauważa również wyjątkowy charakter wstrętu, oraz zjawisko generalizacji wstrętu na coraz szerszą gamę stymulantów: „Wstręt jest uczuciem natury odrębnej. Zrazu odnosił się od do wszystkiego, co było przeciwnym zmysłowi smaku - tak do wrażeń istotnych jak i żywych wyobrażeń z tej sfery - a po tym rozszerzył

\footnotetext{
${ }^{18}$ Felten, Shetty, Atlas neuroanatomii.

${ }^{19}$ Paul Rozin, Jonathan Haidt i Clark R. McCauley, „Digust”, w: Handbook of Emotions. Third Edition, red. Michael Lewis, Janette M. Haviland-Jones, Lisa Feldman Barrett (New York, London: Guilford Press, 2008), 757-776.

${ }^{20}$ Karol Darwin, Wyraz uczuć u człowieka i zwierząt, tłum. Konrad Dobrski (Warszawa: Drukarnia Józefa Sikorskiego, 1873), 227.
} 
się do wszystkiego, co wywoływało podobne wrażenie, bądź to drogą węchu, bądź smaku, a nawet wzroku"21, podkreślając również szczególną bliskość, jaka łączy powonienie i smak: „Ponieważ węch znajduje się w tak ścisłym związku ze smakiem, to nic dziwnego, że nadzwyczajnie zły zapach może u osób niektórych tak łatwo wzbudzić porywy do wymiotów i same wymioty, jak to robi sama myśl o wstrętnej potrawie"22.

Z podobnych założeń wyszli Rozin, Haidt i McCauley, psycholodzy prowadzący badania empiryczne nad emocją wstrętu i analizujący jej ewolucyjne podłoże, którzy wykazali, że w populacji krajów zachodnich jedynie co czwarty bodziec wzbudzający odrazę jest związany z pożywieniem, zwierzętami czy wydzielinami ciał, a źródłami wstrętu są przede wszystkim nieakceptowane praktyki seksualne, niedostatki higieny, śmierć, zniekształcenia i uszkodzenia zewnętrznych powłok ciała (zranienia, deformacje, zakrzepła krew, otyłość), co tłumaczy się jako ewolucyjne poszerzenie naturalnej reakcji obronnej przed zatruciem lub infekcją. Bodźce wywołujące wstręt to takie, które kalają to wszystko, z czym, choćby przelotnie, się stykają, czyniąc je nieczystym. Cytowani badacze sugerują, że pierwotna reakcja obronna, broniąca ciało przed zatruciem lub infekcją, ewoluowała w kierunku mechanizmu chroniącego psychiczny dobrostan, aktywowanego przez coraz bardziej abstrakcyjne bodźce. Z prostego systemu odrzucania materialnych mediów zagrożeń wykształcił się system negatywnej socjalizacji, a wstręt stał się emocją moralną o wysoko niesprecyzowanej dziedzinie stymulatorów, które łączy jedynie to, że są przez daną jednostkę postrzegane jako odpychające ${ }^{23}$. Wstrętne nie jest więc jedynie to, co faktycznie jest biologicznie niebezpieczne, ale wszystko to, co jest w kulturze jako takie arbitralnie uznawane.

$\mathrm{Na}$ binarność ewolucyjnych korzeni reakcji wstrętu u człowieka wskazuje powoływana przez cytowanych autorów hipoteza Daniela R. Kelly’ego, który odróżnia filogenetycznie starszą awersję przed potencjalnie toksycznymi pokar-

\footnotetext{
${ }^{21}$ Tamże, 225.

22 Tamże, 230.

${ }^{23}$ Rozin, Haidt i McCauley, „Digust”; Andras Angyal, „Disgust and related aversions”, The Journal of Abnormal and Social Psychology 36, nr 3 (1941): 393.
} 
mami, związaną przede wszystkim z zachowaniami towarzyszącymi przyjmowaniu pożywienia, a obecną już u zwierząt innych niż człowiek, od kontrakcji specyficznie ludzkiej, związanej z unikaniem pasożytów. Ta druga miałaby, zdaniem Kelly'ego, wyewoluować w odpowiedzi na dywersyfikację źródeł pożywienia zachodzącą u przodków człowieka i wzrost udziału produktów pochodzenia zwierzęcego w jego diecie, ale również ze względu na powiększanie się grup ludzkich, wraz z którym miałoby wzrastać również ryzyko parazytoz. W interpretacji Rozina, Haidta i McCauley'a, z tego pierwotnego niesmaku wstręt ewoluował następnie w kierunku wrażenia wywoływanego przez znacznie szerszą gamę bodźców, takich jak kontakty międzyludzkie czy pogwałcenie norm moralnych.

Materia ze świata zewnętrznego przenika do ciała przeważnie otworami ciała, w tym drogą ustną. Wyrazem lęku przed niechęcią wchłaniania substancji wzbudzających wstręt drogą pokarmową jest powszechnie podzielany przesąd, że człowiek przejmuje własności przyjmowanego pożywienia (w języku polskim ujmowanym we frazę jesteś tym, co jesz) ${ }^{24}$. Rozin, Haidt i McCauley za Andrasem Angyalem uznają, że najsilniejszą reakcję wstrętu wzbudzają wydaliny innych ciał zwierzęcych, postrzegane jako kalające. $Z$ tego powodu pokarmy pochodzenia zwierzęcego wyzwalają, zdaniem tych badaczy, ambiwalentne emocje: są zarazem pożywieniem najsilniej pożądanym i opatrzonym największą liczbą kulturowych zakazów. Niemal we wszystkich znanych kulturach notuje się obecność tabu pokarmowych limitujących spożywanie produktów odzwierzęcych, określających praktyki kulinarne, jakim poddawane są te produkty w celu zapewnienia ich czystości, a także nazewnictwo samego mięsa odmienne od nazw zwierząt, od których pochodzi. Jak zauważają cytowani autorzy, zakazy te dotyczą znacznie rzadziej zwierząt roślinożernych, a częściej zwierząt blisko związanych z człowiekiem

\footnotetext{
${ }^{24}$ Podobne wierzenia obecne są u wielu ludów, a u niektórych przyjmują formę zrytualizowanych zachowań kanibalistycznych powiązanych z przekonaniami o możliwości przejęcia sił fizycznych i intelektualnych przodków poprzez zjadanie części ich ciał, jak miało to miejsce choćby w głośnym, za sprawą zapadalności na prionową chorobę kuru, przypadku członków plemienia Fore z Papui Nowej Gwinei; John Collinge i in., „A clinical study of kuru patients with long incubation periods at the end of the epidemic in Papua New Guinea", Philosophical Transactions of the Royal Society of London B: Biological Sciences 363, nr 1510 (2008): 3725-3739, DOI: https://ddx.doi.org/10.1098/rstb.2008.0068
} 
(przez styczność, jak psy, czy pokrewieństwo, jak prymaty), oraz wyjątkowo dla niego groźnych. Za wstrętne uchodzi również spożywanie pokarmów uznanych za zanieczyszczone, tak przez kontakt ze zwierzętami wzbudzającymi odrazę (w badaniu Rozina, Millmana i Nemeroffa były to sterylnie czyste karaluchy), jak również z darzonymi niechęcią ludźmi (choćby styczność dotyczyła jedynie pojemnika z pożywieniem), co miałoby wynikać z nieuświadomionego lęku przed zakażeniem chorobami. Zjawisko to próbuje się także tłumaczyć żywotnością wyobrażeń wykształconych na gruncie opisanych przez Jamesa Frazera wierzeń z zakresu magii sympatycznej, w szczególności dotyczących prawa styczności, wedle którego oddziaływania między obiektami trwają nieprzerwanie po ustaniu ich fizycznej bliskości ${ }^{25}$.

Ponieważ reakcje wstrętu na bodźce inne niż pokarm nie występują u dzieci przed 3-5 rokiem życia czy u tzw. dzieci dzikich, przyjmuje się, że nastawienie awersyjne wobec innych źródeł odrazy człowiek nabywa w procesie akulturacji. Jednym z najwcześniej nabywanych związków skojarzeniowych w kulturze zachodniej jest uczenie się odrazy wobec odchodów, którą dziecko przejmuje wraz ze zdobywaniem kontroli nad fizjologicznymi czynnościami wypróżniania i wydalania. Wysuwa się przypuszczenie, że doświadczania wstrętu w ekspozycji na kulturowo ustalone bodźce ludzie uczą się przejmując wyraz twarzy osób przeżywających tę emocję, następnie internalizując ją i łącząc z przeżywaniem odrazy właściwej potencjalnym źródłom zatrucia lub skażenia, oraz kojarząc z konkretnymi epizodami, które są następnie generalizowane na inne zjawiska. Od zanieczyszczenia fizycznego, dającego się zniwelować przez takie manipulacje, jak mycie, odróżnia się skażenie niematerialne, „duchowe”, niewrażliwe na praktyki higieniczne, związane ze wstrętem moralnym ${ }^{26}$.

${ }^{25}$ Jako przetrwalniki prawa podobieństwa magii sympatycznej interpretuje się natomiast niechęć wobec pokarmów, które przypominają pożywienie uznawane za nieczyste jedynie swoją formą: jako przykład badacze wymieniają odrazę wobec produktów cukierniczych, przypominających kształtem części ciał zwierząt, których spożywanie obejmuje tabu; Rozin, Haidt i McCauley, „Digust”, 760; James G. Frazer, Złota gałąź, tłum. Henryk Krzeczkowski (Warszawa: Państwowy Instytut Wydawniczy, 1978), 38-68.

${ }^{26}$ Rozin, Haidt i McCauley, „Digust”, 765. 


\begin{tabular}{|c|c|c|c|c|c|}
\hline \multicolumn{5}{|c|}{ Poziomy wstrętu } \\
\hline Funkcja & 0. Niesmak & $\begin{array}{c}1 . \text { Rdzeń } \\
\text { wstrętu }\end{array}$ & $\begin{array}{c}\text { 2. Wstręt } \\
\text { animalny }\end{array}$ & $\begin{array}{c}\text { 3. Wstręt } \\
\text { międzyludzki }\end{array}$ & $\begin{array}{c}4 \text {. Wstręt } \\
\text { moralny }\end{array}$ \\
\hline $\begin{array}{c}\text { przed toksy- } \\
\text { nami }\end{array}$ & $\begin{array}{c}\text { Ochrona } \\
\text { przed infek- } \\
\text { cją }\end{array}$ & $\begin{array}{c}\text { Ochrona } \\
\text { ciała i duszy } \\
\text { przed skaże- } \\
\text { niem moral- } \\
\text { nym }\end{array}$ & $\begin{array}{c}\text { Ochrona } \\
\text { ciała, duszy } \\
\text { i porządku } \\
\text { społecznego }\end{array}$ & $\begin{array}{c}\text { Ochrona } \\
\text { porządku } \\
\text { społecznego }\end{array}$ \\
\hline $\begin{array}{c}\text { Nieprzy- } \\
\text { jące }\end{array}$ & $\begin{array}{c}\text { Pożywienie, } \\
\text { wydzieliny } \\
\text { jemny smak } \\
\text { ciała, zwie- } \\
\text { rzęta }\end{array}$ & $\begin{array}{c}\text { Seks, } \\
\text { swłoki, nie- } \\
\text { dostatki hi- } \\
\text { gieny, de- } \\
\text { formacje } \\
\text { powłok } \\
\text { ciała }\end{array}$ & $\begin{array}{c}\text { Bezpośredni } \\
\text { i pośredni } \\
\text { kontakt z ob- } \\
\text { cymi i wyklu- } \\
\text { czonymi }\end{array}$ & $\begin{array}{c}\text { Naruszenia } \\
\text { norm mo- } \\
\text { ralnych }\end{array}$ \\
\hline
\end{tabular}

Tab. 1. Hipotetyczna ścieżka ewolucyjna rozszerzania się funkcji i dziedziny stymulatorów emocji wstrętu. Oprac. M. K. Przybylska na podstawie Paul Rozin, Jonathan Haidt i Clark R. McCauley, „Digust”, w: Handbook of Emotions. Third Edition, red. Michael Lewis, Janette M. Haviland-Jones, Lisa Feldman Barrett (New York, London: Guilford Press, 2008), 764.

\section{Powonienie, wstręt i społeczno-kulturowe konstruowanie Obcego}

Adekwatnie do hipotezy Rozina, Haidta i McCauley'a, między wstrętem uwarunkowanym biologicznie a wstrętem jako zespołem reakcji nabywanych w procesie akulturacji (konstruowanym społeczno-kulturowo) lokuje się kategoria emocji negatywnych obracających się przeciwko zwierzęcej naturze przeżywającej je osoby (por. tab. 1). Zachowania związane z biologiczną naturą człowieka, 
a potencjalnie odrażające, które autorzy zaliczyli do tej kategorii odpowiadają temu, co M. Douglas opisywała w Czystości i zmazie jako kontrolę fizyczną, przez która społeczeństwo żąda przystosowania od jednostki, tym silniejszą, im silniejszy jest nacisk społecznej sytuacji (tzw. zasada odległości od fizycznego źródła) ${ }^{27}$. Jak zauważa Douglas w innej swej pracy, w judaizmie na przykład nie istnieje możliwość wyobrażenia Boga wyposażonego w organy trawienne i organy wydalania, co nie jest tendencją uniwersalną ${ }^{28}$. Wstręt animalny, międzyludzki, a także moralny, odpowiada temu, co Durkheim rozumiał przez oburzenie, jeden z dwóch psychologicznych czynników, na jakich oparł swoją teorię sacrum² ${ }^{29}$ Do natury wszystkich organizmów żywych należy skończoność ich biologicznego trwania, a wstręt animalny przeciwstawia się również temu aspektowi ich istnienia. Nie tylko same zwłoki, ale i fizjologiczny proces umierania mogą wzbudzać wstręt animalny. Wydaje się, że manifestacji tego rodzaju awersji wobec śmierci i umierania można się współcześnie dopatrywać w zjawisku określanym w tanatoantropologii jako tzw. dziczenie, zanik zdolności oswajania śmierci, polegający na wymazywaniu śmierci z obyczajów i wyobrażeń, a nawet z języka, w którym zastępuje ją szereg eufemizmów i metafor ${ }^{30}$. Jak ujmuje to P. Aries: „Śmierć [...] budzi wstręt, jak każdy odrażający widok. Staje się nieprzyzwoita jak czynności fizjologiczne człowieka, wydzieliny jego ciała. Nieprzyzwoicie jest ukazywać je publicznie. Ludzie nie chcą wpuszczać wszystkich do pokoju cuchnącego moczem, potem, ropą, zabrudzoną pościelą ${ }^{31}$. Śmierć kojarzy się często właśnie ze specyficzną wonią, na co zwraca uwagę M. Mróz w opisie historycznych sposobów ustalania momentu śmierci: „Kolejna strategia, związana z umieraniem i odczytywania momentu śmierci, to strategia olfaktyczna. [...] Najpierw wraz z chorobą człowiek traci tak zwany zapach zdrowia, potem stopniowo zostaje rozpoznany zapach śmierci. Choroba, szczególnie śmiertelna, bywała rozpoznawana po woni [...] Woń śmierci jest tak bezpośrednia i przemożna, że z kolei zrodzi z czasem praktykę czystości

${ }^{27}$ Mary Douglas, Czystość i zmaza, tłum. Marta Bucholc (Warszawa: Państwowy Instytut Wydawniczy, 2007).

${ }^{28}$ Tejże, Symbole naturalne. Rozważania o kosmologii, tłum. Ewa Dżurak (Kraków: Wydawnictwo Uniwersytetu Jagiellońskiego, 2004), 35.

${ }^{29}$ Tamże, 15.

${ }^{30}$ Philippe Aries, Człowiek i śmierć, tłum. Eligia Bąkowska (Warszawa: Państwowy Instytut Wydawniczy, 1989), 41.

${ }^{31}$ Tamże, 544. 
i izolacji [...] Ingerencja w ciało [...] uzyska społeczną akceptację pewnego „oszukiwania” śmierci poprzez usuwanie tej dotychczas odczuwanej „woni śmierci”32.

Martwe ludzkie ciało, czy to w przypadku wyparcia zdziczałej śmierci, czy to poddawane zrytualizowanym zabiegom mającym umożliwić zmarłemu przejście do nowej sytuacji społecznej, nie jest nigdy „naszym” ciałem: jest ciałem Innego, albo też trup jest pierwszym Obcym. Ponieważ wstręt związany z bliskością śmierci jest wtrętem animalnym, jego podłoże jedynie do pewnego stopnia związane jest ze skonkretyzowanymi zjawiskami biologicznymi. Znajduje to odbicie $\mathrm{w}$ obecnej w chrześcijaństwie praktyce in odore sanctitatis, związanej z orzekaniem o świętości zmarłej osoby na podstawie zapachu jej zwłok. Zwyczaj ten opisuje S. Grygiel, odwołując się do przykładu zaczerpniętego z Braci Karamazow Dostojewskiego. Przytaczany przez tego autora fragment ilustruje scenę nawiązującą do autentycznych historycznych wydarzeń, w której ludność przybyła po śmierci starca, jeszcze za życia uznawanego za świętego, gwałtownie nabiera wątpliwości co do jego moralności pod wpływem zapachu rozkładu wydzielanego przez jego zwłoki. Woń towarzysząca naturalnej deterioracji ciała wznieca instynktowny lęk przed śmiercią, a broniąc się przed nim, wierni poszukują w zjawisku całkowicie organicznym przejawu boskiej interwencji. Zgromadzeni usiłują siebie przekonać, że obecności trupa towarzyszy odór i zaduch, ale nie dlatego, że jest to efektem chemicznych przemian, lecz dlatego, że sąd boży inny jest od ludzkiego, na co umyślnie chciał Bóg wskazać, co wywołało powszechne brutalnie wyuzdane zgorszenie. Jak wywodzi dalej autor za L.-V. Thomasem, od niektórych trupów oczekiwano „słodkiego” zapachu, ponieważ doczesnym szczątkom świętych przypisuje się $\mathrm{w}$ chrześcijaństwie znaczenie magiczno-religijne - nie mogą więc, podobnie jak judaistyczny Bóg, podlegać tym przemianom i procesom fizjologicznym, które wzbudzają wstręt animalny. Grygiel przytacza również następujący fragment $\hat{S} w$. IdiotyCezarego Wodzińskiego, dotyczący nadzwyczajnych zjawisk, które według tradycji prawosławnej towarzyszą zgonom świętych starców, wśród których wymienia się: cudowne znaki, jak "nieziemskie wonności, którymi wypełnia się całe miasto"33.

${ }^{32}$ Mirosław Mróz, „Śmierć człowieka w ujęciu teologicznym a ewoluujące pojęcie śmierci biologicznej”, Udar Mózgu. Problemy Interdyscyplinarne 8, nr 2 (2006): 49-58.

${ }^{33}$ Szymon Grygiel, „Ciało i świętość. Przypadek XIX-wiecznych świętych starców rosyjskich”, Adeptus 2017, nr 9: 1-21, DOI: https://dx.doi.org/10.11649/a.1417 
Z nakreślonym przez S. Grygiela obrazem koresponduje praca W. Zyzaka, w której wskazuje on na konkretne sposoby odczuwania przez wspólnotę wiernych obecności sacrum w relikwiach, towarzyszące im znaki świętości, wśród których wymienia: blask, zachowanie ciała od rozkładu, czy właśnie cudowną woń. Autor podkreśla również społeczną rolę, jaką odgrywają relikwie dla wspólnoty wiernych: biorą one udział w tworzeniu „poczucia wspólnoty zarówno na płaszczyźnie kościelnej, jak i świeckiej"34.

Rola pięknej woni w kreowaniu zdarzeń w rzeczywistości społecznej znajduje wyraz w zabiegach, jakim tradycyjnie i rytualnie, całkowicie niezależnie od modnej tanatopraksji, poddaje się ciało zmarłego, np. w obrzędzie incesacji, czyli rytualnym okadzaniu ciała zmarłego ${ }^{35}$. Znaczenie woni w duchowości chrześcijańskiej odkrywa również liturgia bierzmowania, w której celebrans zwraca się do przyjmujących sakrament: „aby [...] wasze życie było w każdym miejscy dobrą wonią Chrystusa, bowiem otrzymują znamię Pańskie, razem z Darem Ducha Świętego, który doskonalej upodabnia go do Chrystusa i udziela mu łaski rozszerzania wśród ludzi „dobrej woni” (por. 2 Kor. 2, 14) ${ }^{36}$. W trakcie poświęcania krzyżma odmawiana jest modlitwa, w której pojawia się wezwanie: „Niech wszyscy ochrzczeni przeniknięci świętym namaszczeniem i uwolnieni od grzechu pierworodnego staną się Twoją świątynią i wydają woń niewinnego życia" ${ }^{\text {". }}$. Woń odgrywa znaczenie rytualne nie tylko w chrześcijaństwie, czy judaizmie, ale pod postacią choćby okadzania, znajduje wyraz w rozlicznych kultach. Czynności tej przypisuje się symboliczne znaczenie „upowietrzniania”, sypirytualizacji, czynienia materialnego duchowym ${ }^{38}$.

Znacznie wyższym stopniem wyabstrahowania w stosunku do biologicznego podłoża cechuje się, według hipotezy Rozina, Haidta i McCauley’a, wstręt na poziomie międzyludzkim: nadal można tu mówić o emocji, której podstawowy sens

${ }^{34}$ Wojciech Zyzak, „Zmysły duchowe w duchowości chrześcijańskiej”, Analecta Cracoviensia 2016, nr 48: 255-276, DOI: https://dx.doi.org/10.15633/acr.2026

${ }^{35}$ Marian Wańczowski, Mirosław Lenart, współ. Małgorzta Burzak-Janik, Marek Kawa, Ewa Maciesowicz, Marek Szladowski, Księga żałoby i śmierci (Warszawa: Oficyna Wydawnicza RYTM, 2009), 170 .

${ }^{36}$ Święta Kongregacja Kultu Bożego, „Obrzędy bierzmowania”, Ruch Biblijny i Liturgiczny 28, nr 1-2 (1975): 7-18, DOI: https://dx.doi.org/10.21906/rbl.3274

${ }^{37}$ Zbigniew Kiernikowski, „Krzyżmo Chrystusa i chrześcijanina”, Liturgia.pl, https://www.liturgia.pl/Krzyzmo-Chrystusa-i-chrzescijanina/ (dostęp: 19.11.2018).

${ }^{38}$ Wańczowski i Lenart, Księga żałoby i śmierci, 321. 
ewolucyjny polega na ochronie ciała, jednak istotniejsza w tym przypadku staje się ochrona społecznego porządku i na tym poziomie co, jak wyżej wspomniano, sugerował Kelly, w związku z rozwojem liczebności grup ludzkich i zwiększonym ryzykiem infekcji pasożytami, pojawia się wstręt odczuwany w stosunku do obcych (por. Tab. 1.). Obcymi są oczywiście nie tylko ludzie przynależący do innych grup, ale także wszyscy ci, na których zachowanie solidarna społeczność reaguje uczuciem oburzenia i których jednostkowe odchylenia od norm opatruje etykietą świętej nieczystości ${ }^{39}$. We wzbudzaniu tego szczególnego wstrętu ważną rolę odgrywają językowe określenia odwołujące się do opisu nieprzyjemnego zapachu, jaki wydzielają ciała obcych.

Historyk francuski A. Corbin w pracy We władzy wstrętu przytacza cały wachlarz przykładów opisujących dzielenie społeczeństwa przez kreowanie wyobrażeń konstruujących segregację, których narzędziem staje się wstręt wzniecany przez odór. Cuchną nie tylko przedstawiciele niższych kast społecznych, ludzie biedni, ludzie-gnój, ale smród ma również wymiar ksenofobiczny, na przykład w odniesieniu do Żydów: „Wszędzie tam [...] gdzie owi Hebrajczycy są zgromadzeni i gdzie im samym zostawia się pieczę nad porządkiem w obrębie ich obszaru, odór jest szczególnie silny". Z drugiej strony, to właśnie odór niweluje różnice społeczne w przypadku ludzi uzależnionych od nikotyny: „Człowiek, który pali, jest równy człowiekowi, który pali [...] bogaty i biedny ocierają się o siebie bez zdziwienia w miejscach, gdzie sprzedaje się tyton'"40.

W Polsce nie brak podobnych przykładów. Już J. S. Bystroń zauważał, że rozpowszechnionemu w Polsce przekonaniu o własnej narodowej wyższości towarzyszy negatywny obraz językowy obcych, co znajduje również wyraz w pejoratywnych określeniach opisujących woń wydzielaną przez ich ciała. I tak mówiło się na przykład o przykrym zapachu obcych, który wynikać miał wprost z tego, że obcy byli urodzeni inaczej, to znaczy, że nie przyszli na świat odpowiednim otworem przy urodzeniu, lecz śmierdzącym. Wiara Polaków we własną wspaniałość, która Bystroń odmalowuje, przejawia się w przekonaniu o niezwykłym swoim sprycie, które odcisnęło się w przypowiastkach o diabłach przechytrzonych przez przeciętnych ludzi. Diabeł stara się zamaskować swoją piekielną tożsamość, zdradza go jednak odpychający zapach: „[...] jedynie przezorni ludzie mogą poznać,

\footnotetext{
${ }^{39}$ Douglas, Symbole naturalne, 15.

${ }^{40}$ Alain Corbin, We władzy wstrętu: społeczna historia poznania przez węch: od odrazy do snu ekologicznego, tłum. Andrzej Siemek (Warszawa: Oficyna Wydawnicza Volumen, 1998).
} 
i to najczęściej po chodzie (gdyż nogę jedną ma zakończoną kopytem), po jednej tylko dziurce $\mathrm{w}$ nosie lub też zupełnym braku, wreszcie po zapachu (kozłem śmierdzi: diabeł") ${ }^{41}$.

L. Stomma przytacza inne przykłady wypowiedzi świadczących o niechętnym stosunku do obcych: „Wydzielają wreszcie obcy intensywne, acz nie nazbyt przyjemne zapachy. »Co tu, u diabła, tak czosnek zalatuje, panie Klejn?« - pyta pan Lisiecki na widok nowego subiekta, Henryka Szlangbauma. Szykana ta oparta jest na starym ludowym przekonaniu, iż $» \grave{y d}$ cuchnie czosnkiem i cebulą, Rosjanin - wódką, Niemiec - gównem, a Francuzom od jaj zalatuje«, przy czym ostatni człon przytoczonej formuły związany jest z wyobrażeniem ogromnych narządów płciowych, jakie posiadać mają m. in. Francuzi, górale i (pogląd notowany od niedawna) Murzyni” ${ }^{\prime 2}$. Nie wyczerpuje to jeszcze katalogu wzbudzających wstręt, „śmierdzących” obcych.

O ile w przypadku odoru wódki, czosnku czy fekaliów można przypuszczać, że jest to woń związana ze zwyczajami i z zachowaniem obcych, a więc nie jest trwała, nieusuwalna, niepoddająca się manipulacjom higienicznym, to w szczególnych przypadkach napotyka się również świadectwa, które wprost odnoszą się do biologicznej odmienności obcych. Komunikaty operujące takimi stwierdzeniami wydają się szczególnie ofensywne, ponieważ w tym przypadku nie próbuje się uzasadniać niechęci wobec obcych ich odrażającym zapachem, wynikającym z nieprzestrzegania określonych norm: taki język osadza zjawisko właściwe wstrętowi poziomu międzyludzkiego w zjawiskach związanych ze wstrętem bardziej konkretnym i pierwotnym. W takich sytuacjach E. Nowicka, która badała stosunek członków społeczności wiejskich wobec Romów, zanotowała następujące spostrzeżenia i wypowiedzi: „Drugą ich cechą fizyczną jest, [...] nieprzyjemny zapach, który wydzielają ich ciała. Mycie się, pranie ubrania nie likwiduje, w pojęciu przynajmniej niektórych, tego odstręczającego odoru. Bliska sąsiadka Romów [...] tak mówi: »Mają swój zapach taki. Ci mieszańcy to nie mają tego zapachu, bo już pomieszani. Np. dawniej, jak koninę jedli, to gdy do klasy się wchodziło, to był straszny smród«. I dalej: »W chałupach raczej czysto, ale jest zapach taki. Może jak ktoś nie wie, to nie, ale my tu poznamy, że to Cygan«. Pokój wynajęty pew-

\footnotetext{
${ }^{41}$ Jan S. Bystroń, Megalomania narodowa (Warszawa: Książka i Wiedza, 1995).

${ }^{42}$ Ludwik Stomma, Antropologia kultury wsi polskiej XIX wieku (Warszawa: Instytut Wydawniczy PAX, 1986).
} 
nemu panu, który okazał się być Romem, a przyjechał odwiedzić osiedle w Czarnej Górze po uroczystościach w Oświęcimiu, też wydawał charakterystyczny odór - jak mówi ta sama kobieta: »Po nim pokój śmierdział. Śmierdział Cyganem«. Nauczycielka z Czarnej Góry, urodzona w tej wsi, podobnie mówi o nieprzyjemnym zapachu Cyganów: »Mają inny zapach, czy to odżywianie, czy pot inny? To nieprzyjemny zapach. To niezależnie od tego czy się myją, chociaż to inna sprawa, bo od tych bogatych to tak nie czuć, a jak dziewczyny jeszcze mają okres! «”33.

Wstrętna woń, jaką wydzielać mają przedstawiciele grupy odmiennej etnicznie, jest tu prezentowana jako rezultat różnic istniejących rzekomo na poziomie fizjologicznym, przy czym różnice te są postrzegane jako niedające się niwelować czy maskować („niezależnie od tego czy się myją”). Przywodzi to na myśl strategie odczłowieczające. W badaniach nad przyczynami agresji i przemocy w relacjach między grupami ludzkimi wskazywano już na zjawisko tzw. dehumanizacji. W swojej teoretycznej analizie tego zjawiska Haslam rozróżniał dehumanizację polegającą na pozbawianiu ludzi człowieczeństwa przez nadawanie im cech zwierzęcych (animalistic dehumanization) oraz operującą określeniami zbliżającymi jednostki odczłowieczane do niegodnych empatii automatów, odmawiającymi im przeżywania właściwym ludziom emocji (mechanistic dehumanization) wskazując przy tym, że wstrętem operuje specyficznie ta pierwsza, „animalna”, zezwierzęcająca strategia dehumanizacyjna ${ }^{44}$.

\section{Podsumowanie}

Woń emitowana ciało i rozpoznawanie tej woni jest u większości organizmów odpowiedzialna za regulację zachowań społecznych, tytułowe unikanie, uległość i troskę. Z racji wysokiej biologicznej istotności opracowywanych danych, węch, pod względem potencjału oddziaływania na system limbiczny człowieka, jest zmysłem, w stosunku do wszystkich pozostałych biologicznie „preferowanym”, dlatego siła jego potencjalnego oddziaływania na układ limbiczny

${ }^{43}$ Ewa Nowicka, „Rom jako swój i jako obcy: zbiorowość Romów w świadomości społeczności wiejskiej”, Lud 1995, nr 78: 357-375.

${ }^{44}$ Nick Haslam, „Dehumanization: An integrative review”, Personality and Social Psychology Review 10, nr 3 (2006): 252-264, DOI: https://dx.doi.org/10.1207/s15327957pspr1003_4 
człowieka jest wyraźnie niedoszacowana. Różnica w stopniu, w jakim informacja zapachowa jest świadomie analizowana, w stosunku do informacji pochodzących z innych modalności zmysłowych przyczynia się do tego, że woń wpływa na reakcje emocjonalne bardzo efektywnie, choć często sam fakt wpływu nie jest odnotowywany. Węch, ze względu na ewolucyjne podłoże wstrętu, łatwo generuje przeżywanie odrazy. Sam wstręt jest emocją związaną z reakcją odpychania i stanowi aktywną barierę behawioralną przed źródłami skażenia. Pierwotna rola wstrętu polegała najprawdopodobniej nie na realizacji określonych programów zachowania, ale na hamowaniu popędu przyjmowania pokarmu. W postaci zgeneralizowanej doświadczanie wstrętu może generować silny dysonans poznawczy w stosunku do skłonności do odczuwania empatii i potrzeby niesienia pomocy. Z powodu zapośredniczenia przez doświadczanie wstrętu, posługiwanie się wyobrażeniami odwołującymi się do woni ciała jest skutecznym i niebezpiecznym narzędziem społeczno-kulturowego wykluczenia. Ponieważ sam wstręt moralny jest już emocją silnie wyabstrahowaną od jej biologicznego podłoża, opisy odnoszące się do woni ciała przedstawicieli grup wykluczanych mogą być groźnie skutecznym narzędziem konstruowania podziałów międzyludzkich, niezależnie od stopnia realizacji praktyk higienicznych (na co wskazują choćby przytoczone wyżej wypowiedzi rozmówców E. Nowickiej: „niezależnie od tego, czy się myją”). Z tego powodu wypowiedzi rasistowskie i ksenofobiczne, operujące wyrażeniami odnoszącymi się do głębokich, negatywnych skojarzeń z „biologiczną” wonią ciała przedstawicieli mniejszości etnicznych i innych, powinny wzbudzać szczególną czujność również współcześnie.

\section{Bibliografia}

Angyal, Andras. „Disgust and related aversions”. The Journal of Abnormal and Social Psychology 36, nr 3 (1941): 393-412.

Aries, Philippe. Człowiek i śmierć. Tłum. Eligia Bąkowska. Warszawa: Państwowy Instytut Wydawniczy, 1989.

Billen, Johan. „Exocrine glands and their key function in the communication system of social insects". Formosan Entomology 2011, nr 31: 75-84.

Buck, Linda i Richard Axel. „A novel multigene family may encode odorant receptors: a molecular basis for odor recognition". Cell 65, $\mathrm{nr} 1$ (1991): 175-187. DOI: https://dx.doi.org/10.1016/0092-8674(91)90418-x 
Pobrane z czasopisma http://kulturaiwartosci.journals.umes.pl

Bystroń, Jan S. Megalomania narodowa. Warszawa: Książka i Wiedza, 1995.

Collinge, John, Jerome Whitfield, Edward McKintosh, Adam Frosh, Simon Mead, Andrew F. Hill, Sebastian Brandner, Dafydd Thomas i Michael P. Alpers. „A clinical study of kuru patients with long incubation periods at the end of the epidemic in Papua New Guinea". Philosophical Transactions of the Royal Society of London B: Biological Sciences 363, nr 1510 (2008): 3725-3739. DOI: https://dx.doi.org/10.1098/rstb.2008.0068

Corbin, Alain. We władzy wstrętu: społeczna historia poznania przez węch: od odrazy do snu ekologicznego. Tłum. Andrzej Siemek. Warszawa: Oficyna Wydawnicza Volumen, 1998.

Darwin, Karol. Wyraz uczuć u człowieka i zwierząt. Tłum. Konrad Dobrski. Warszawa: Drukarnia Józefa Sikorskiego, 1873.

Davies, David G., Matthew R. Parsek, James P. Pearson, Barbara H. Iglewski, John W. Costerton, Everett P. Greenberg. "The involvement of cell-to-cell signals in the development of a bacterial biofilm". Science 280, nr 5361 (1998): 295-298. DOI: https://dx.doi.org/10.1126/science.280.5361.295

Dias, Brian G. i Kerry J. Ressler. „Parental olfactory experience influences behavior and neural structure in subsequent generations". Nature neuroscience 17, nr 1 (2014): 89-96. DOI: https://dx.doi.org/10.1038/nn.3594

Douglas, Mary. Czystość i zmaza. Tłum. Marta Bucholc. Warszawa: Państwowy Instytut Wydawniczy, 2007.

Douglas, Mary. Symbole naturalne. Rozważania o kosmologii. Tłum. Ewa Dżurak. Kraków: Wydawnictwo Uniwersytetu Jagiellońskiego, 2004.

Dunny, Gary M., Timothy J. Brickman i Martin S. Dworkin. „Multicellular behavior in bacteria: communication, cooperation, competition and cheating”. BioEseys 30, nr 4 (2008): 296298. DOI: https://dx.doi.org/10.1002/bies.20740

Felten, David F., Anil N. Shetty. Atlas neuroanatomii i neurofizjologii Nettera, red. wydania polskiego Andrzej Szczudlik. Wrocław: Elsevier Urban \& Partner, 2012.

Frazer, George J. Złota gałąź. Tłum. Henryk Krzeczkowski. Warszawa: Państwowy Instytut Wydawniczy, 1978.

Grygiel, Szymon. „Ciało i świętość. Przypadek XIX-wiecznych świętych starców rosyjskich”. Adeptus 2017, nr 9: 1-21. DOI: https://dx.doi.org/10.11649/a.1417

Haslam, Nick. „Dehumanization: An integrative review”. Personality and Social Psychology Review 10, nr 3 (2006): 252-264. DOI: https://dx.doi.org/10.1207/s15327957pspr1003_4

Hughes, Sylvia. „Antelope Activate the Acacia's Alarm System”. New Scientist 127, nr 29 (1990): 19.

Karban, Richard, Kaori Shiojiri. „Self-recognition affects plant communication and defence”. Ecology Letters 12, nr 6 (2009): 502-506. DOI: https://dx.doi.org/10.1111/j.14610248.2009.01313.x

Karban, Richard, Kaori Shiojiri, Satomi Ishizaki, William C. Wetzel i Richard Y. Evans. „Kin recognition affects plant communication and defence". Proceedings of the Royal Society B 280, nr 1756 (2013): 1-5. DOI: https://dx.doi.org/10.1098/rspb.2012.3062 
Karban, Richard, Louie H. Yang i Kyle F. Edwards. „Volatile communication between plants that affects herbivory: a meta-analysis”. Ecology Letters 17, nr 1 (2014): 44-52.

Kiernikowski, Zbigniew. „Krzyżmo Chrystusa i chrześcijanina”. Liturgia.pl, https://www.liturgia.pl/Krzyzmo-Chrystusa-i-chrzescijanina. Dostęp: 19.11.2018.

Miler, Dagmara. „Pozyskiwanie dowodu przy wykorzystaniu ekspertyzy osmologicznej”. W: Katalog dowodów w postępowaniu karnym, red. Paweł Czarnecki, Małgorzata Czerwińska, 257-268. Warszawa: Wydawnictwo C. H. Beck, 2014.

Mróz, Mirosław. „Śmierć człowieka w ujęciu teologicznym a ewoluujące pojęcie śmierci biologicznej”. Udar Mózgu. Problemy Interdyscyplinarne 8, nr 2 (2006): 49-58.

Nowicka, Ewa. „Rom jako swój i jako obcy: zbiorowość Romów w świadomości społeczności wiejskiej”. Lud 1995, nr 78: 357-375.

Passador, Luciano, James M. Cook, Michael J. Gambello, Lynn Rust i Barbara H. Iglewski. „Expression of Pseudomonas aeruginosa virulence genes requires cell-to-cell communication”. Science 260, $\mathrm{nr} 5111$ (1993): 1127-1130. DOI: https://dx.doi.org/10.1126/science.8493556

Polese, Gianluca, Carla Bertapelle i Anna Di Cosmo. „Role of olfaction in Octopus vulgaris reproduction". General and Coparative Endocrinology 210, $\mathrm{nr} 1$ (2015): 55-62. DOI: https://dx.doi.org/10.1016/j.ygcen.2014.10.006

Pokrospki, Marek. Cielesna geneza czasu i przestrzeni. Warszawa: Wydawnictwo IFiS PAN, 2013.

Porter, Jess, Brent Craven, Rehan M. Khan, Shao-Ju Chang, Irene Kang, Benjamin Judkewicz, Jason Volpe, Gary Settles i Noam Sobel. „Mechanisms of scent-tracking in humans”. Nature neuroscience 10, nr 1 (2007): 27-29. DOI: https://dx.doi.org/10.1038/nn1819.

Richard, Freddie-Jeanne i James H. Hunt, „Intracolony chemical communication in social insects". Insectes Sociaux 60, $\mathrm{nr} 3$ (2013): 275-291. DOI: https:// dx.doi.org/10.1007/s00040-013-0306-6

Rozin, Paul, Jonathan Haidt, i Clark R. McCauley. „Digust”. W: Handbook of Emotions. Third Edition, red. Michael Lewis, Janette M. Haviland-Jones, Lisa Feldman Barrett, 757-776. New York, London: Guilford Press, 2008.

Shirasu, Mika i Kazushige Touhara. „The scent of disease: volatile organic compounds of the human body related to disease and disorder". The Journal of Biochemistry 150, nr 3 (2011): 257-266. DOI: https://dx.doi.org/10.1093/jb/mvr090

Singer, Tania, Ben Seymour, John P. O’Doherty, Klaas E. Stephan, Raymond J. Dolan i Chris D. Frith. „Empathic neural responses are modulated by the perceived fairness of others”. Nature 439, nr 7075 (2008): 466-469. DOI: https://dx.doi.org/10.1038/nature04271

Stomma, Ludwik. Antropologia kultury wsi polskiej XIX wieku. Warszawa: Instytut Wydawniczy PAX, 1986.

Süskind, Patrick. Pachnidło, Historia pewnego mordercy. Tłum. Małgorzata Łukasiewicz. Warszawa: Świat Książki, 2006.

Szyf, Moshe. „Lamarck revisited: epigenetic inheritance of ancestral odor fear conditioning”. Nature Neuroscience 17, nr 1 (2014): 2-4. DOI: https://dx.doi.org/10.1038/nn.3603 
Święta Kongregacja Kultu Bożego. „Obrzędy bierzmowania”. Ruch Biblijny i Liturgiczny 28, nr 1-2 (1975): 7-18. DOI: https://dx.doi.org/10.21906/rbl.3274

Wańczowski, Marian, Mirosław Lenart, współ. Małgorzata Burzak-Janik, Marek Kawa, Ewa Maciesowicz, Marek Szladowski. Księga żałoby i śmierci. Warszawa: Oficyna Wydawnicza RYTM, 2009.

Wojciech Zyzak, „Zmysły duchowe w duchowości chrześcijańskiej”, Analecta Cracoviensia 2016, nr 48: 255-276. DOI: https://dx.doi.org/10.15633/acr.2026

\title{
Summary
}

Avoidance, submission, concern... The body's smell in the social and cultural construction of the Stranger

The significance of olfaction in social communication and perceptional alignment of people has not been fully recognized in humanities but interest in this issue has been nascent in recent years. And that also in cross-cultural research. The matter is analyzed in the article from an evolutionary, historical and neurobiological perspective. The purpose is to show that perception of the human body's smell can most effectively shape people's attitudes to others. The author attempts to identify biological mechanisms potentially determining the effectiveness of odor as a cultural tool defining social boundaries and identifying individuals as "one of us", "someone", or "a stranger."

Keywords: olfaction, body odor, disgust, evolution of disgust, stranger, exclusion

\author{
Zusammenfassung \\ Vermeiden, Unterwürfigkeit, Pflege... Der Geruch des Körpers \\ in der sozial-kulturellen Konstruktion des Fremden
}

Die Bewusstwerdung der Bedeutung des Geruchssinns in der Erkenntnis des Menschen in den Geisteswissenschaften kann als ungenügend betrachtet werden, obwohl in den letzten Jahren ein Zuwachs an Interesse an dieser Thematik auch unter den Kulturforschern zu beobachten ist. Im vorliegenden Artikel wird die Rolle des Geruchs in der sozialen Erkenntnis des Menschen aus der evolutionären, historischen und neurobiologischen Perspektive untersucht. Es galt aufzuzeigen, dass das Herausbilden von Einstellungen gegenüber anderen äußerst effektiv mit den Vorstellungen operieren kann, die sich auf den Körpergeruch beziehen. Es wird 
nach biologischen Mechanismen gesucht, die potentiell über die Wirksamkeit der Geruchsbezüge als eines Kulturwerkzeugs entscheiden, das soziale Grenzen absteckt und die Wahrnehmung von Individuen in den Kategorien des Eigenen und des Anderen / Fremden manipuliert. Die Verfasserin setzt sich zum Ziel, das Bewusstsein der möglichen Effektivität des ausgrenzenden Einflusses der Sprache hinsichtlich des Körpergeruchs zu steigern sowie die Wachsamkeit bei den Empfängern solcher Mitteilungen zu wecken.

Schlüsselworte: Geruchssinn, Körpergeruch, Ekel, die Evolution des Ekels, Ausgrenzung

Information about Author:

MARIA KATARZYNA PRZYBYLSKA, Institute of Philosophy, Faculty of Humanities, Nicolaus Copernicus University; address for correspondence: ul. Fosa Staromiejska 1a, PL 87100 Toruń; e-mail: stellaskygge@gmail.com 